AGRICA, 3 (1) : 63 - 69 (2010)

ISSN : 1979-0368

\title{
PERANAN PESTISIDA BOTANI DALAM MENDUKUNG PERTANIAN ORGANIK
}

\author{
I Putu Sudiarta \\ Departement of Agroecotechnology, Faculty of Agriculture, Udayana University \\ Jl. P. B. Sudirman Denpasar Bali, 80325 \\ Email: putu.ueda@yahoo.com
}

\section{SUMMARY}

\section{The Role Of Botanical Pesticides In The Support Of Organic Agriculture}

Until recently the use of synthetic pesticides to control pests and plant diseases proved effective, but on the other hand the excessive use of synthetic pesticides cause many negative effects, such as development of pest and disease resistance, second pest explosion, death of natural enemies and pesticide residues in food and environment. One alternative that can be done to solve this problem is the use of botanical pesticides. Botanical pesticides are compounds produced as a plant defense response to disturbances and stimulation. These compounds generally are of secondary metabolites that have many functions, such as growth hormones (Auxin, gibberellins and cytokinins), anti-fungal or anti-bacterial, antibiotics, and toxic to animals and insects. The advantage of botanical pesticides is that they have toxicity similar to synthetic pesticides, but the botanical pesticides can be rapidly decomposed naturally by oxygen or sunlight, so they are appropriate to be used to support sustainable organic agriculture.

Experiments in the utilization of botanical pesticides to control plant pests have been carried out. One example application is the use of botanical insecticides from 'brotowali' leaf extract(Tinospora crispa) to control the diamond black caterpillars (Plutella xylostella) on cabbage plants. In addition, the use of 'basil' oil (Ocimum tenuiflorum) has a real impact in population control of the fruit fly (Bactrocera dorsalis). In addition to pest control, botanical pesticides are also reported to effectively control plant diseases.Use of 'galangal' (Alpinia galanga) and papaya (Carica papaya) has a high ability to inhibit the growth of Ceratocystis sp. on PDA and fruits. The combination of 'betel' leaf extract (Piper betle) and 'galangal' ( $A$. galanga) can suppress the growth of banana wilt disease caused by Fusarium oxysporum and / or the Ralstonia solanacearum. The use of 'galangal'(A. galanga) extract with a concentration of 5\%, can also inhibit the growth of stem rot disease $(F$. oxisporum ) on vanilla seedlings. In addition, the use of 'betel' leaf $P$. betle in the field can suppress black rot disease on cocoa pods (cocoa black pod disease).

Key words: botanical pesticides, environmental sustainability, organic farming

\section{PENDAHULUAN}

Peningkatan penduduk dunia (sekitar 400 kali setahun) dan persediaan bahan pangan telah menjadi topik hangat pembahasan masyarakat dunia. Pada tahun 1850 penduduk dunia berjumlah 1 milyar jiwa, pada tahun 1999 berjumlah 6 milyar jiwa dan pada tahun 2025 diperkirakan akan mencapai 8 milyar jiwa (Sastrodiharjo, 2003). 
Peningkatan penduduk dan kebutuhan akan pangan semakin hari semakin meningkat sedangkan lahan pertanian yang produktif semakin menurun. Dalam rangka pemecahan masalah tersebut maka pada tahun 1992, UNCED (United Nations Conference on Environmental and Development) merekomendasikan konsep Sustainable Development (Djuniadi, 2003). Hasil konferensi tersebut menyatakan bahwa pembangunan berkelanjutan harus memperhatikan aspek sossial, ekonomi, dan ekologi pada tingkat lokal, regional dan global yang mempunyai tujuan utama meningkatkan produksi pangan dan ketahanan pangan secara berkesinambungan.

Salah satu komponen yang berperan dalam menunjang kesuksesan produksi pangan tersebut adalah pestisida (Untung, 1996). Penggunaan pestisida sintetik di Indonesia hingga kini dirasakan sangat penting dan menyebabkan ketergantungan terhadap petani. Petani percaya berdasarkan pengalamannya tanpa pestisda mereka tidak dapat berproduksi secara maksimal bahkan bisa mengakibatkan gagal panen. Intensitas pemakaian pestisida sintetik di Indonesia sangat tinggi mencapai 20.000 ton/tahun dengan nilai Rp. 250 milyar. Pada tahun 2000, pestisida yang terdaftar pada komisi pestisida mencapai 594 merek dagang (Novizan, 2002). Penggunaan pestisida sintetik yang tinggi tersebut kini disadari memiliki dampak negatif, diantaranya adalah resistensi hama, resurgensi, ledakan hama kedua, matinya musuh alami, residu pada makanan dan pencemaran lingkungan. Menurut WHO (World Health Organization) paling tidak 20.000 orang meninggal per tahun akibat keracunan pestisida, sekitar 5.000-10.000 orang pertahun mengalami dampak fatal seperti kanker, cacat tubuh kemandulan dan penyakit liver (Novizan, 2002). Selain itu setelah dihapuskannya subsidi pestisida di Indonesia mengakibatkan harga pestisida yang mahal dan sangat sulit dijangkau oleh petani. Berdasarkan hal tersebut, perlu sebuah alternatif pengendalian atau komplemennya, yang bisa dimanfaatkan dari kekayaan lokal dan dihasilkan secara lokal sehingga terjangkau oleh petani.

Pestisida alternatif tersebut dapat diproleh dari senyawa aktif biologis yang terdapat pada tumbuhan lokal. Secara tradisional hal tersebut sebenarnya telah dikenal oleh petani sejak lama (Sudiarta and Suprapta, 2007). Senyawa biologis tersebut secara umum mudah ditemui, memiliki daya racun rendah terhadap mamalia, dapat diproduksi dalam skala rumah tangga dan mudah mengalami biodegradasi sehingga diperkirakan tidak berbahaya bagi lingkungan. Potensi pestisida botani di Indonesia sangat terbuka lebar, diperkirakan ada sebanyak 20.000 spesies tumbuhan berbunga yang tumbuh di Indonesia, dan diperkirakan kurang dari $10 \%$ yang diketahui kandungan kimia serta manfaatnya bagi manusia secara langsung (Suprapta, 2003). Beberapa pestisida botani telah diteliti dan mampu menekan pertumbuhan hama maupun penyakit tumbuhan (Suprapta et al., 2001; Suprapta et al., 2003; Suprapta et al., 2005a; Suprapta et al., 2005b). Berdasarkan keunggulan pestisida botani tersebut, maka sangatlah mungkin untuk terus dikembangkan sehingga pertanian organik yang berkelanjutan dan kelestarian lingkungan dapat diwujudkan.

\section{ULASAN}

\section{Sejarah Pestisida Botani}

Pestisida botani memiliki sejarah panjang dan telah menjadi tradisi bangsa-bangsa di dunia untuk 
melindungi tanaman dari serangan hama dan penyakit. Bangsa Romawi Kuno telah menggunakan minyak zaitun sebagai pestisida. Nimba telah banyak dipakai sebagai insektisida di India dan sekarang India telah menjadi produsen pestisida botani berbahan aktif mimba. Pestisida botani adalah senyawa organic yang tersusun oleh $\mathrm{C}, \mathrm{H}, \mathrm{O}, \mathrm{N}, \mathrm{P}, \mathrm{K}$ dan unsur-unsur umum lainnya. Kebanyakan pestisida botani dapat dicerna oleh organisme, mengalami breakdown oleh panas, oksigen dan sinar matahari (Suprapta, 2003). Pestisida botani merupakan senyawa yang dihasilkan sebagai respon pertahanan tumbuhan terhadap gangguan herbivore. Senyawa tersebut umumnya adalah berupa metabolit sekunder yang memiliki banyak fungsi, seperti hormon tumbuh (auxin, gibberellins dan cytokinins), anti jamur, antibiotik dan bersifat toksik bagi binatang dan serangga. Sifat racun tersebut diantanya adalah berupa alkaloids dan cyanogenic glycosides, bisa juga memiliki rasa pahit sehingga bersifat feeding deterrents bagi serangga (Vickery and Vikery, 1981). Menurut Novizan (2002) fungsi persisida botani dalam mengendalikan organisme pengganggu tumbuhan (OPT), adalah: repellents, yaitu menolak kehadiran serangga, terutama disebabkan baunya yang menyengat. Feeding deterrent, mencegah serangga makan tanaman yang telah disemprot, terutama disebabkan rasanya yang pahit. Mencegah serangga meletakkan telur dan menghentikan proses penetasan telur. Bersifat racun saraf, mengacaukan sistem hormone dalam tubuh serangga. Attractant, sebagai penarik serangga. Sebagai anti jamur (fungisida) dan anti bakteri (bakterisida).

\section{Beberapa Contoh Pestisida Botani a. Rotenon}

Rotenon merupakan insektisida yang ditemukan pada akar tuba (Derris elliptica) yang tersebar di seluruh Indonesia. Rotenone juga diekstrak dari akar tanaman Lonchocarpus spp. Rotenone murni sangat beracun melebihi pestisida sintetik dari golongan karbaril dan malathion. Walaupun kandungan racunnya tinggi namun rotenone sangat mudah terurai dalam hitungan hari. Rotenon lebih efektif digunakan sebagai racun perut dibandingkan racun kontak. Insektisida tersebut bekerja dengan cara menghambat respirasi sel, berdampak pada saraf dan otot yang menyebabkan serangga berhenti makan, sehingga kematian serangga terjadi cukup lama bahkan beberapa hari (Ling, 2003; Hinson, 2000; Sudiarta and Suprapta, 2006).

\section{b. Nikotin}

Nikotin adalah insiktisida alkaloid yang diekstrak dari daun dan batang tembakau (Nicotiana tabacum). Kandungan nikotin terbesar pada ranting dan tulang daun. Daun kering tembakau mengandung 2-8\% nikotin (Nivizan, 2002). Dibandingkan rotenone, pada dosis yang sama nicotin 30 kali lebih toksik. Daya toksik nikotin tidak dapat melindungi tanaman dalam jangka waktu lama, karean terurai cepat secara alamiah oleh sinar matahari. Nikotin merupakan racun saraf yang bekerja sangat cepat. Aplikasi nikotin sebagai racun kontak dapat digunakan pada serangga bertubuh lunak seperti ulat, apis, trips, kutu daun dan pengujiannya di laboratorium biasanya menggunakan kecoa Periplaneta americana (Grolleau et al. 1996).

\section{c. Piretrum dan piretrin}

Tanaman

krisan

(Chrysanthemum cinerariaefolium) merupakan tanaman penghasil bahan aktif piretrum dan peritrin. Tanaman ini 
bukan tanaman asli Indonesia, namun kini sudah banyak dibudidayakan sebagai tanaman hias. Piretrum umumnya mengandung $0.9-1.3 \%$ piretrin. Piretrin merupakan racun saraf yang bekerja sangat cepat dan mengakibatkan serangga knockdown secara langsung. Namun demikian serangga akan sadar kembali, karena piretrin dapat diuraikan melalui metabolisme dalam tubuhnya. Untuk mengatasi hal tersebut, bisaanya produk komersial ditambahkan PBO (Piperonyl Butoxide) yang berfungsi menghambat metabolisme sel, sehingga piretrin bekerja maksimal (Godin, et al. 1965; Qureshi , et al. 2002; Sudiarta and Suprapta, 2006; Wanyika et al. 2009).

\section{d. Mimba (Neem)}

Mimba diekstrak dari daun dan

biji tanaman mimba (Azadirachta indica) yang pertama kali ditemukan di India. Pada tanaman mimba mengandung senyawa yang bersifat toksik yaitu azadirachtin, meliatriol, nimbin dan salannin. Mimba merupakan insektisida yang sangat umum digunakan untuk mengendalikan banyak serangga, menurut Sastrodiharjo (1990) mimba dapat mengendalikan 75 jenis serangga. India dan Afrika telah menggunakan mimba sebagai insektisida lebih dari 400 tahun. Mimba dapat mengganggu hormone produksi dan pertumbuhan serangga, sehingga mencegah serangga mengalami kematangan seksual. Selain itu bau mimba dapat bersifat repellent terhadap serangga. Rasa mimba yang pahit bersifat sebagai anti feedan bagi serangga, sehingg serangga kurang menyukai tanaman yang disemprot dengan ekstrak mimba (Mondal, et al. 2007; Qureshi , et al. 2002; Sudiarta and Suprapta, 2006).

\section{Peranan dan penerapan pestisida botani}

\section{a. Insektisida}

Penggunaan pestisida sintetik yang berlebihan telah banyak diteliti meninbulkan dampak negatif, salah satu alternatif yang potensial digunakan adalah perstisida botani. Pemanfatan perstisida botani untuk mengendaliakan serangga hama telah banyak dilakukan. Suprapta et al. (2003) melaporka insektisida botani yang diperoleh dari ekstrak daun brotowali Tinospora crispa mampu menekan aktivitas makan ulat diamond black (Plutella xylostella) di laboratorium dan lapangan pada tanaman kubis. Penerapan ekstrak daun T. crispa di lapangan pada konsentrasi $0.1-1.0 \%$ menunjukkan beda nyata terhadap kepadatan larva $P$. xylostella. Hasil penelitian tersebut menunjukkan bahwa, kepadatan larva pada plot yang disemprot dengan ekstrak daun $T$. crispa $0.1 \%$ adalah 6.8 larval/plant berbeda nyata dengan plot pada konsntrasi 1\% (1.6 larval/plant).

Pemanfaatan pestisida botani
sebagai pengendali hama juga
dilaporkan oleh Sumiartha et al.,
(2005). Hasil penelitian tersebut menunjukkan bahwa, perlakuan minyak selasih (Ocimum tenuiflorum) atau metil eugenol komersial pada berbagai konsentrasi (20\%-100\%) memiliki dampak yang nyata terhadap tangkapan lalat buah (Bactrocera dorsalis complex). Perlakuan minyak selasih dengan konsentrasi $80 \%$ menunjukkan tangkapan $B$. dorsalis yang paling tinggi dibandingkan pada konsentrasi lainnya. Jumlah B. dorsalis pada trap/perangkap dengan perlakuan minyak selasih dan metal eugenol komersial tidak berbeda nyata. Hasil penelitian tersebut juga menunjukkan bahwa, jumlah tangkapan $B$. dorsalis paling rendah pada hari ke30 setelah perlakuan. 


\section{b. Fungisida}

Hasil penelitian menunjukan bahwa fungisida botani terbukti efektif mengendalikan jamur pathogen pada bebagai tanaman inang. Suprapta et al., (2001) melaporkan bahwa, dari 15 ekstrak tanaman yang diuji, 2 diantanya yaitu: umbi lengkuas (Alpinia galanga) dan daun pepaya (Carica papaya) memilili aktivitas paling tinggi menghambat pertumbuhan Ceratocystis sp. Daya hambat $A$. galanga pada konsentrasi $5 \%$ di PDA mencapai $92.5 \%$ dan $C$. papaya mampu menghambat $73.3 \%$. Daya hambat $A$. galanga dan $C$. papaya juga ditunjukan pada potongan buah salak yang sebelumnya telah dicelupkan pada ekstrak tanaman tersebut. Selian itu Suprapta et al. (2008) melaporkan penggunaan kombinasi beberapa ekstrak tanaman dapat menekan penyakit busuk hitam pada buah kakao (cocoa black pod disease) yang disebabkan oleh Phytophthora palmivora di lapangan.

\section{SIMPULAN}

Penggunaan pestisida botani adalah salah satu alternatif untuk mengurangi penggunaan pestisda sintetik dalam ranggka mewujudkan pertanian organik yang berkelanjutan. Hal tersebut secara utama bertujaun untuk menunjang kebutuhan pangan nasional, dan mengurangi dampak negatif peenggunaan pestisida sintetik yang berlebihan. Selain itu sasaran utama penggunaan pestisida botani adalah bisa dimanfaatkan oleh petani secara mudah dan murah, dengan memanfaatkan sumberdaya alam lokal yang tersedia.

\section{DAFTAR PUSTAKA}

Djuniadi D. 2003. Peranan Industri pada Pengelolaan Hama Terpadu dalam Pertanian Berkelanjutan. Kongres
Perhimpunan Entomologi Indonesia dan Simposium Entomologi VI 2003. Cipayung. pp. 17-26.

Godin, P. J., J. H. Stevenson, R. M. Sawicki, 1965. The Insecticidal Activity of Jasmolin II and Its Isolation from Pyrethrum (Chrysanthemum cinerariaefolium Vis.). Journal of economic entomology 58 (3): 548-551(4)

Grolleau, F. B. Lapied, S. D. Buckingham, W. T. Mason, and D. B. Sattelle . 1996. Nicotine increases $[\mathrm{Ca} 2+] \mathrm{i}$ and regulates electrical activity in insect neurosecretory cells (DUM neurons) via an acetylcholine receptor with 'mixed' nicotinicmuscarinic pharmacology. Neuroscience Letters 220: 142146.

Hinson, D. 2000. Rotenone characterization and toxicity in aquatic system. University of Idaho Principles of environmental toxicology. $13 \mathrm{p}$.

Ling, N. 2003. Rotenone a review of its toxicity and use for fisheries management. Science for conservation 211, Department of Conservation P.O. Box 10-420, Wellington, New Zealand. 40 p.

Mondal D., S. Barat, and M. K. Mukhopadhyay. 2007. Toxicity of neem pesticides on a fresh water loach, Lepidocephalichthys guntea (Hamilton Buchanan) of Darjeeling district in West Bengal. Journal of Environmental Biology. 28(1): 119-122. 
Novizan. 2002. Membuat \& Memanfaatkan Pestisida Ramah Lingkungan. AgroMedia Pustaka. Jakarta. 94 p.

Qureshi M. S., T. A. Jackson, R. J. Townsend and D. J. Saville. 2002. Toxicity of Neem and Pyrethrum Extracts to Adult Grass Grub. New Zealand Plant Protection Society (Inc.) www.nzpps.org Refer to http://www.nzpps.org/terms_of_us e.html. pp. 298-302.

Sudiarta, P. and D. N. Suprapta. 2006. Development of Botanical Pesticide to Support Sustainable Agriculture. Proceeding International Workshop Ibaraki University Japan, pp. 108-111.

Sudiarta, P. and D. N. Suprapta. 2007. Present Status of Traditional Farming System of Local Rice in Bali, International Student Workshop 2007. Ibaraki University Japan.

Sastrodihardjo $\quad$ S. 1990. Mengembangkan Produk Alami, Kususnya dari Mimba (Azadiracta indica) untuk Pestisida. Seminar Pengelolaan Serangga Hama dan Tungau dengan Sumber Hayati. Bandung. pp.1-6.

Sumiartha K., W. Susila and P. Sudiarta. 2005. Effect of "Selasih" (Ocimum tenuiflorum) Plant Oil on Fruit Flies (Bactrocera dorsalis Complex) in Long Chili. Journal of ISSAAS 11(3)(Sppl.): 150-155.

Suprapta, D. N., M. Sudana and N. Arya. 2001. Application of Plant Extracts to Control Ceratocystis
Fruit Rot in Snake Fruit (Salacca edulis). Journal of ISSAAS 7: 1016.

Suprapta, D. N., I W. Suanda, N. Arya and K. Ohsawa. 2003. Insecticidal Activity of Tinospora crispa Leaf Extract Against Diamond Back Moth in Cabbage. Journal of ISSAAS 9(2): 18-24.

Suprapta, D. N. 2003. The Use of Local Plant as Botanical Pesticide to Increase Selfness of Farmer. The Speech Inauguration as Professor in Department of Plant Insects and Diseases, Faculty of Agriculture, Udayana University. 33 p.

Suprapta, D. N., M. Sudarma, N. Arya and K. Ohsawa. 2005a. Plant Extracts to Control Wild Disease in Banana Seedlings. Journal of ISSAAS 11(2): 84-90.

Suprapta, D. N., M. Sudarma and K. Ohsawa. 2005b. Fungicidal Activity of Alpinia galanga Extract Against Fusarium oxysporum f.sp. vanillae, The Casual Agent of Stem Rot Disease on Vanilla. Journal of ISSAAS 11(3)(Sppl.): 150-155.

Suprapta, D. N. M. Sudana, G. N. Alit Susanta Wirya and P. Sudiarta. 2008. Plant Extracts to Control Cocoa Black Pod Disease Caused by Phytophthora palmivora. J. ISSAAS. 13 (3) Suppl: 21-31.

Untung, K. 1996. Pengantar Pengelolaan Hama Terpadu. Gajah Mada University Press. Yogyakarta. 273 p.

Vickery M. L. and B. Vickery. 1981. Secondary Plant Metabolism. 
University Park Press. Baltimore. $328 \mathrm{p}$.

Wanyika H. N., P.G. Kareru, J.M.

Keriko, A.N. Gachanja, G.M.

Kenji and N.J Mukiira. 2009.

Contact toxicity of some fixed plant oils and stabilized natural pyrethrum extracts against adult maize weevils (Sitophilus zeamais Motschulsky). African Journal of Pharmacy and Pharmacology 3(2): 066-069. 